\title{
Melting the Kachinas: Agricultural Hegemony and Indigenous Incorporation at Zuni Pueblo in the Modern Era
}

\author{
Eric Perramond ${ }^{1}$ \\ Colorado College
}

\section{Introduction}

It is ironic that our understanding of indigenous agricultural landscapes in the Americas is perhaps more sophisticated for Pre-Columbian contexts than for colonial and modern ones (K. Butzer 1992; W. Denevan 1992; W. Doolittle 1992, 2000). Interest in reconstructing these past landscapes, real or imagined, has largely stemmed from archaeology and geoarchaeology focusing on site-specific studies (K. Butzer 1982; cf S. Fish and P. Fish 1984). The assumption has been that indigenous agricultural techniques and landscapes are no longer what they were before European colonization. In contrast, there is ample work on the colonial stasis of cultural institutions, implying a continuous connection or accretion to the past (T. Maxwell 1956; D. Gade 1992).

Intensive agricultural practices were limited to a few regions of North America, especially north of Mexico, but even these are not well studied (cf. W. Doolittle 2000). In what is today the U.S. Southwest, the agricultural land management practices of the Pueblo Groups were found along the Rio Grande in New Mexico with a few outliers to the west. The Zuni reservation (Figure 1) is located along the western border of New Mexico, abutting the state of Arizona, although the area traditionally used by the Zuni was once much larger (E. Hart 1985). The Zuni are part of what anthropologists have classified as the "Pueblo Indian” culture group, although there were of course significant linguistic differences between the Pueblo cultures. $^{2}$

This paper explores the rather neglected aspect of landscape transformation and indigenous response on the Zuni reservation that took place between 1880 to 1930. It examines the influence of practices dating from this colonial period on modern land uses and agriculture. ${ }^{3}$ The actions of the United States government and its agencies during this time constituted a form of neo-colonialism in the historical geographies of many indigenous groups in the region. And despite the cultural resilience and persistence of the Zuni, fragments of Federal policy come through suggestively, especially in regards to traditional agricultural practices. For example among the Zuni farmers I interviewed as part of my research in the early 1990s, many were reluctant to question "scientific" opinion or findings about their own agricultural or animal practices (E. Perramond 1994). Only four (of eighty-four) informants openly debated bureaucratic or "expert" opinion regarding their past or current forms of agriculture and animal husbandry. This process of 'knowledge disenfranchisement' bears further examination.

\footnotetext{
${ }^{1}$ I wish to thank the Zuni Sustainable Agriculture Project personnel, namely David Cleveland, Daniela Solieri, Daniel Eriacho, Francis Bowannie (Jr) and Andrew Laahty, for their help and support during the original research for this study. The Zuni Conservation Project director at the time, Jim Enote, also granted access to the archives and photo collections duplicated form the National Archives (listed as "Na" in bibliography for use of archival materials) and now stored at Zuni Pueblo. I thank T.J. Ferguson for allowing me to access and use original interviews collected for legal claims of the Zuni. Early research on this project was generously supported by the Robert C. West field research fund in the Department of Geography \& Anthropology at Louisiana State University. Follow-up archival research was conducted at the National Archives and Library of Congress in 1998. A recent version of the manuscript was reviewed and critiqued by former colleagues Paul Croce, Joel Davis, Eric Kurlander, Emily Mieras and Bob Sitler - and by Simon Batterbury, Karl Offen and Andrew Sluyter - none of whom are responsible for any lingering errors or limitations. Email: Eric.Perramond "at" ColoradoCollege.edu

2 "Pueblo" in Spanish simply means "town" or "inhabited site," so the original distinction and label given by the Spanish were an attempt to explain that these groups were more "civilized" or at least "urbanized" than the other nomadic indigenous peoples encountered in the Greater Southwest. The term "pueblo" is used to describe the main settlement nucleus on the Zuni reservation of west-central New Mexico.

${ }^{3}$ By "colonial period," I mean both the lingering after-effects and real changes during the Spanish Colonial Period (at Zuni, ca 1598-1821) and the period under U.S. Federal rule (1850s - present). Although rarely have indigenous peoples in the U.S. been seen as victims of a domestic form of colonialism, the same discourses of racial superiority (and inferiority), economic underdevelopment, and physical domination are apparent in the U.S. as they were in, say, British and French colonies of Africa and South Asia.
} 


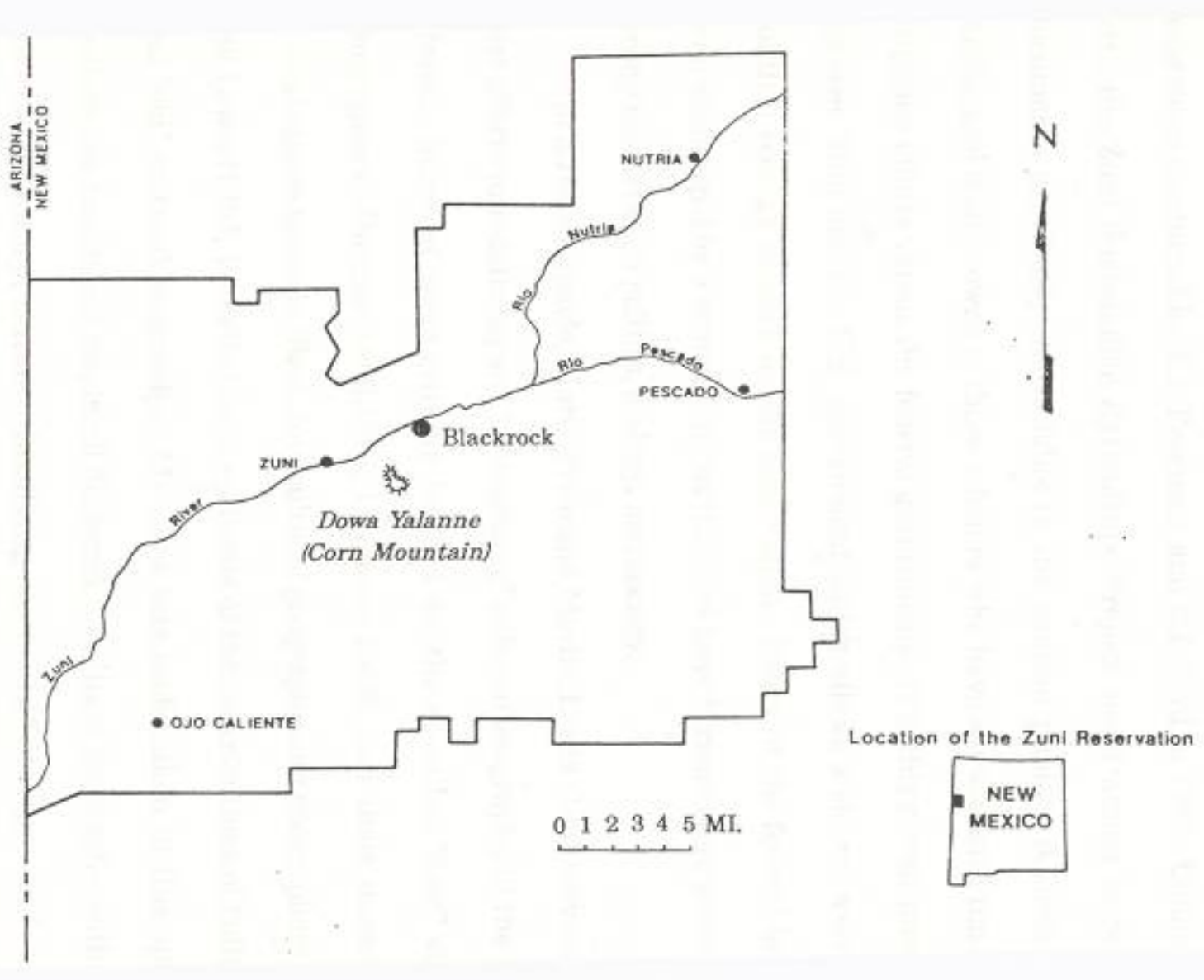

Figure 1. Context of Zuni Pueblo in the Four Corners region of the American Southwest

The variety of agricultural practices and landscapes in the Zuni region is well documented by past work (T. Ferguson and E. Hart 1985). Floodwater farming, canal irrigation, dryland agriculture through sand dune cultivation, and intensive gardening were all practiced by the Zuni prior to Spanish contact (K. Kintigh 1985). Livestock raising, principally in the form of sheep and cattle, was added as a crucial supplement to Zuni livelihoods during the Spanish Colonial period. Some orchard crops were also added by the Spanish missionary activity in the area, and relicts of peach trees are still visible today on the sides of Dowa Yalanne (Corn Mountain), the large mesa that dominates the area just south of Zuni the town (D. Cleveland et al 1995). The contemporary Zuni landscape, however, belies the complexity of the region's "historical political ecology" (K. Offen 2004).

Political ecology directs us towards the influence of institutions, political economy and the varieties of "development discourse" as they relate to indigenous landscapes (R. Peet and M. Watts 1996; K. Zimmerer 1996; T. Bassett 2001). The majority of the work in this field, despite some roots in historical investigation (P. Blaikie and H. Brookfield 1987; E. Swyngedouw 1999; A. Sluyter 2002; K. Offen 2004), adopts a synchronic perspective, poorly addressing the evolution and variation over time of these same processes or factors. By contrast, in this paper I trace the historical, geographic, and political components of the landscape and ideological (discursive) changes that have taken place at Zuni. After a brief introduction to the historical context and study area, I explore the discursive formation of indigenous policies during the modern period at Zuni, tracing its manifestation in today's reservation landscape. By using a field- 
informed approach to primary, historical documents and the secondary literature, the articulation of hegemony at Zuni is illustrated and explained. ${ }^{4}$

\section{National Ideas of Indigenous Incorporation}

Since the inception of the United States in 1776, the overall policies of the Federal government towards Native Americans were intended to either "assimilate" or "exterminate" them (F. Prucha 1988). For almost a full century, little attention was paid to any question of "Indian policy", as removal was by far the most common solution to a crowded Eastern seaboard. For the Zuni, this meant that after the wholesale abandonment by the Spanish of their far Northern imperial borderlands after the 1820s, little contact with Anglo-Americans ensued, until the 1860s. By the 1830s a permanent "Indian country" west of the Mississippi was adopted. In 1832, Congress created the bureaucratic roots of the Bureau of Indian Affairs, then named the Commission of Indian Affairs. By the 1850s, however, this ideal of a "separation of Indians and whites along an east-west axis was in shambles" (R. White 1991, pp.87-91). The so-called reservation system emerged then only as a spontaneous, accidental solution for Native American sovereignty and spatial management. Yet a social change was emerging in the midst of this reservation movement. White (1991, p. 108) has labeled this subtle transition as a move from "sovereignty to wardship.” All reform policies during the assimilation campaign consisted of three components.

First, the native social organizations, religions and household economies had to be crushed and reconsolidated. Second, the education of Amerindian children would instill "mainstream American Protestant values in place of tribal values" (R. White 1991, p. 110). The final component was the allotment strategy for disintegrating communal or traditional arrangements of land-use and land tenure on reservation lands (F. Hoxie 1984). This last component, as will be clear, is vital to understanding the landscape changes that occurred at Zuni, in terms of bio-physical transformations, and in terms of land tenure. The legal rhetoric invoked the formulation of domestic dependent nations within a larger nation, thus the Federal government would administer its "Indian wards as if they were incompetent children" (R. White 1991, p. 108). In 1887, Congress implemented the Dawes Severalty Act in an effort to make "Indians" formal "land-owners". Recognition of Indian land ownership was aimed at privatizing communal resources in an effort to civilize and transform the Natives into land-owning entrepreneurial farmers. If they failed, these peoples could then simply be absorbed into the national economy as wage labor, and their lands could be used for more useful purposes (Horsman 1978, p. 32). In not dissimilar ways, this "nationalization" of indigenous lands was a precursor to contemporary trends, the neo-liberalization and privatization of communal resources, but one that occurred at Zuni between the Dawes Act and the early $20^{\mathrm{H}}$ Century.

This division of communal plots would supposedly ease the assimilation process for Native Americans. Once fragmentation of sufficient land and resources had occurred, the remaining lands and waters could go to European and American settlers (Hagan 1988, pp. 59-61). Concordant with the physical shattering of communal management systems, Zuni social and religious systems were to be dismantled, especially through the use of certain institutions. The main target in these circumstances was the traditional Zuni council of elders, typically described by Anglo-Americans as a "theocracy". The influence of a "proper education" was one of the most powerful tools with which the Federal government broke indigenous belief systems and traditional resource management practices (R. White 1991, p. 113). Schools at Zuni held true to this pattern, and Protestant missionaries operated many educational establishments during the height of this assimilationist movement (1880s-1920s). There was a gradual shift in policy and motives from isolating Amerindians, through to assimilation.

Underlying the cooperation between Federal agencies was the firm belief that the twin national goals of "efficiency and economic development" would be achieved by these policies. The fast route to native dependency on a Federal bureaucracy was certainly speeded by these newly-formed bureaucratic agreements (F. Hoxie 1984, p. 173; R. White 1984). It could be argued that this was an attempt to create a new form of ethnic class in the United States - an "irony" of assimilation, as Hoxie (1984, p. 241) has put it, in that they were to be incorporated into the new society but were never expected to achieve the same socio-economic status as equals "of their conquerors". This strain of assimilation and ideology survives to this day in much of the literature within the Bureau of Indian Affairs (henceforth the BIA). What is critical

\footnotetext{
4 This aspect of “field-informed re-interpretation of primary historical documents" is a point much emphasized by Offen $(2004,21)$ to complement the ethnographic, contemporary work typically done in anthropology and geography.
} 
is understanding that for Zuni landscapes and livelihoods, these efforts were both tackled on ideological grounds and physical "policing" efforts, to alter indigenous culture and forms of agriculture.

\section{Agricultural Hegemony}

Based on Antonio Gramsci's (1971) concept of "cultural hegemony," the extension to a form of agricultural hegemony is not a geographic stretch of the imagination, but rather, a perfect illustration of the physicality and spatiality of the changes wrought by U.S. government policy on Zuni agricultural beliefs and practices. ${ }^{5}$ Although the term, even in Gramsci's own texts, was not uniformly defined or applied, the concept of hegemony as applied to material landscape transformations holds great promise. This, in spite of most current use and understanding of hegemony as some simple form of power or ideology, rather than as an approach to understanding power (D. Kurtz 1996; K. Crehan 2002). By "hegemony," Gramsci (1971, pp. 12-13) was referring to two simultaneous, dialectic processes, one shaped on ideological consent, the other more physical in terms of power. Each facet of hegemony, however, was discursive: simple imposition of consensus or brute force is rare. ${ }^{6}$ Vogeler (1996) has used the concept of hegemony implicitly in this sense in describing East Germany's attempts to transform agricultural landscapes. Makabe (1999) referred to the concept of "ethnic hegemony" in discussing Japanese dominance of a Brazilian sector of agriculture. And Crehan (2002, esp. ch 7) has similarly integrated Gramscian conceptions into cultural questions of anthropological concern.

Among political ecologists, Donald Moore (1996) has employed the most refined application of Gramscian thought to resource struggles and material-ideological transformative practices. Yet, as Crehan (2002, p172) notes, most uses by social scientists have amounted to what she terms "hegemony lite." Keesing (1994) based his analysis of colonial and anti-colonial discourses in Melanesia almost completely on the ideological underpinnings of Gramsci's ideas, rather than the actual, physical transformative effect that hegemony can display. ${ }^{7}$ Here, I use agricultural hegemony to describe the actions taken by U.S. Federal officials to managing or transform the productive landscapes on the Zuni reservation. In many ways, the discourse of agricultural modernization used at Zuni prefigures the recurrent language and tools used in the postwar Third World development literature to describe similar phenomena (R. Peet and M. Watts 1996, pp. 22-23).

In Zuni, the repetitive indoctrination through education, technological extension, and privatization or allotment of communal lands did lead to agricultural modernization. Missionary activity on the reservation also provided a more "universalizing" morality for the changes sought by the Federal agents at Zuni. The devaluation of traditional Zuni ceremonial icons such as kachinas, worked as an instrument of discipline, and this led to the gradual replacement of beliefs: from animistic, landscape-based values to ones centered on technical practices and science. ${ }^{8}$ The practices and responses of this hegemony have been ambivalent, highly dependent upon each BIA Commissioner’s praxis and the reactions of the Zuni Council to it. Efforts were made to restore certain practices and beliefs at Zuni during the 1990s. Yet many of the

${ }^{5}$ By "spatiality," I mean simply the self-understood boundaries of Zuni space by the Zuni themselves, as well as the changing spatial conditions of their reservation and the imposed geometry of BIA maps.

${ }^{6}$ In Gramsci’s own words, hegemony was comprised of:

1. The "spontaneous" consent given by the great masses of the population to the general direction imposed on social life by the dominant fundamental group; this consent is "historically" caused by the prestige (and consequent confidence) which the dominant group enjoys because of its position and function in the world of production.

2. The apparatus of state coercive power which "legally" enforces discipline on those groups who do not "consent" either actively or passively. This apparatus is, however, constituted for the whole of society in anticipation of moments of crisis of command and direction when spontaneous consent has failed. - (A. Gramsci 1971, p. 12).

${ }^{7}$ Crehan (2002) makes this accusation because of the absence of a balanced use of the term in Keesing (1994) in his Melanesian examples.

${ }^{8}$ Kachinas, also known as "koko" at Zuni, have quite different meanings. While also used by the Hopi in Northern Arizona, at Zuni the kachinas are principally evident during the December Shalako ceremonies. The Zuni kachinas tend to be represented as birds, but have also been flexibly used as terms to describe mountain spirits, or as indicators of the hunting season. 
recommendations now pitched as scientific or objective in tone are somehow regarded as "common sense" and accepted doctrine on the reservation. Gramsci's agricultural hegemony is valuable in explaining why.

The early phases of agricultural hegemony were slow and incremental, and the reform of Zuni agriculture depended on mapping and understanding the boundaries of cultural spaces and physical places. The Federal government employed topographers and cartographers in the mid- $19^{\text {th }}$ Century to connect the geopolitical dots of the region. While many of these maps were accurate, they were never value-free images of reality. As Brian Harley (1988, p. 278) argued, "maps are a way of conceiving, articulating, and structuring the human world which is biased towards, promoted by, and exerts influence upon particular sets of social relations." In this case, the "text" of maps was based towards "extractive" knowledge of the Zuni landscape, fixing these Amerindians in time and place, and placing price-tags, possibilities and labels on the surrounding landscape. This utilitarian classification of Zuni's landscapes coincided with a growing concern to raise agricultural productivity on the reservation at all costs. Nature was bounty: grasses and shrubs became "production." The pines and junipers of the Zuni region and watershed were reduced to "good timber," and rare animal species were biological "anomalies" in the often sterile accounts of early explorers and reservation officials. In sum, this corner of the Southwest fits nicely into Foucault's "squared and spatialized” development of natural history” (D. Spurr 1993, p. 63).

The way in which the Anglo-Americans conceived of their new environment and the longestablished cultures is interesting. In the early contact texts, we can see the first strains of social Darwinism, of cultural prejudice and disdain, and of judgments based on material productivity and "efficiency." These scientific expeditions determined which Amerindians were "more or less primitive" than others. Scientists and explorers, not to mention reservation officials, relied on a system of simple inventory classification of natural landscapes and creatures (M. Pratt 1991, pp. 24-5). The Zuni were simply one more addition to this naturalized landscape to be classified. This aspect has been implied in past work, but never emphasized: the assumption was that the Zuni were not responsible for the landscape. The landscape, in other words, could not be cultural. To admit this would have negated the mission of the preliminary scientific expeditions into the American Southwest, and their biological inventories and maps.

When praise was later extended to Zuni agricultural practices and landscapes, it was with one eye on accumulation, and their progressive integration as private land-owners. A. Whipple, an expedition leader for the U.S. government in 1853, recounted the Zuni as "miserable wretches, bearing unmistakable signs of incipient or waning disease," but in the same breath would praise them for being industrious in agriculture and their ability to create productive corn crops without the aide of irrigation (G. Forman 1941, pp. 141-2, 148-9). Another observer noted that "these people seem to have discovered the principal of industrial accumulation, and therefore of social progress, more than any Indians I have seen” (J. Simpson 1964, p. 125). The Zuni were now viewed through the "paradigm of modernization" (D. Spurr 1993, p. 71) and efforts at breaking the cultural identity of the Zuni invoked some form of this new kaleidoscope of social evolution.

These passages also invoke the powerful ambiguity of intellectuals and officials in the assertion of agricultural hegemony. Praise and scorn are mixed liberally, certainly displaying an ambivalent attitude towards both the Zuni and the project of modernizing this group, anticipating the real discursive push to change Zuni lives and landscapes.

The first hint of agricultural hegemony appears in the historical record when the commander at Fort Defiance gave the Zuni four steel plows in 1856 (Figure 2). It was the first gesture of what was to become the overriding concern of Federal policy: “To introduce American technology to the Zuni” (B. Mills et al 1982, p. 27). Indian agents for the Federal government promised gifts of American technology to the Zuni as well. Mowing machines, wire, spades, axes, picks and scythes were some of the most sought-after articles (E. Hart 1985, p. 175). These items, by themselves, were most welcomed by the Zuni. Fundamentally, the adoption and integration of tools fit nicely with Zuni production strategies, still focused at that time on subsistence. Technology itself, however, is not the fundamental driver for agricultural hegemony. Worster's (1985) taxonomy of agricultural systems in the West is useful for illustrating and understanding many of the changes that occurred at Zuni in the late $19^{\text {th }}$ and early $20^{\text {th }}$ centuries as part of this hegemony remaking of livelihoods.

\footnotetext{
${ }^{9}$ The term "common sense” is a slippery one when discussing the ideas and use of such phrasing in Gramsci’s original texts. By this, in Italian, Gramsci was most commonly using the meaning of "good sense." It does not, however, excuse the inner contradiction of using "common" and "good” sense interchangeably in much of his notes.
} 
Worster classifies extant agricultural systems at the time into "modes” of production: local, agrarian and capitalist. In his "local subsistence mode," production techniques are reliant upon "temporary structures and small-scale permanent works that interfere only minimally with the natural flow of streams" (D. Worster 1985, p. 31). Granted, the Zuni were adept at modifying and diverting ephemeral and perennial streams onto fields, in both floodwater and canal irrigation contexts. The balance of these intensive practices with extensive ones (such as grazing) at Zuni, however, cannot be viewed as a "primitive agricultural economy." This early notion of a primitive economy denies the skill and local knowledge involved in adapting new crops and information into the Zuni subsistence system, a corpus of information which is certainly valued today (D. Cleveland 1998). Second, the Zuni maintained tight control over certain types of resources, and developed definite regulations over resource use. Third, we cannot apply this schema of agricultural production "modes" too closely. There is not clear "evolution" from one form of production mode to the next, for good reasons.

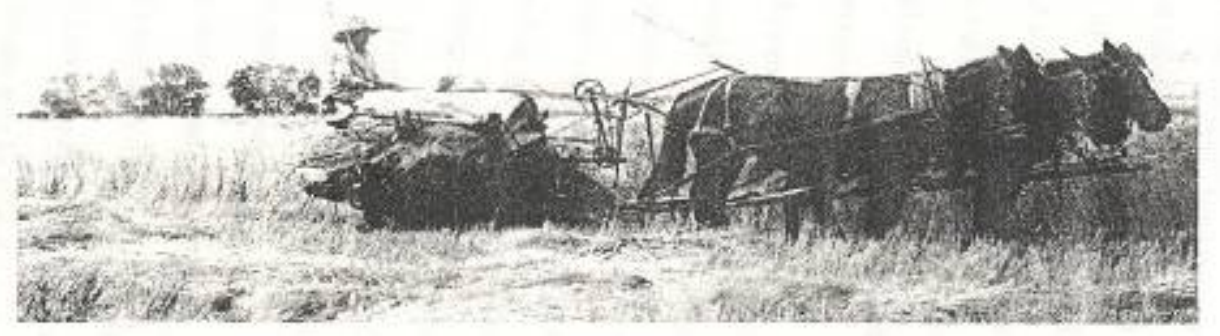

Figure 2. Horse-drawn steel wheat thresher at Zuni, ca. 1930.

Photo Courtesy of National Archives collection at Zuni Pueblo.

Worster's (1985, p. 37) second mode of production is termed the “agrarian state mode." Here, a small community interacts with some form of ill-defined state power, to gain access to the state's water control system. This certainly does not describe the Spanish presence at Zuni, as even the missionaries were never fully in control of agriculture or the practices involved, such that the Zuni were being coerced into leaping from subsistence into the "capitalist" mode of production. It does more accurately capture the process occurring at Zuni during the period between 1880-1920, as the U.S. Federal government was attempting to gain control of Zuni water resources. This final mode revolved around two groups: "a private sector of agriculturalists and public sector made up of bureaucratic planners and elected representatives. Neither group is autonomous” (D. Worster 1985, p. 51). With some modification to this final mode of production, a degree of utility to Worster's framework can be seen in light of the Zuni example. Much like Gramsci's original criticism of Marx, however, Worster's overly economistic and structural taxonomy lacks cultural refinement. The Zuni, for example, were never a "private sector of agriculturalists" as much of their land tenure was based on usufruct rights not outright ownership of lands. In addition, while the administrators and officers working for the Bureau of Indian Affairs were indeed "bureaucratic planners" they were actually quite autonomous in their ability to make decisions. ${ }^{10}$ Here, too, a Gramscian perspective on experts (or "intellectuals" as Gramsci prefers) and bureaucrats is illustrative. Early commissioners of Indian Affairs at Zuni were well aware of both the challenge of changing Zuni culture, and the limitations and tools that were at their disposal for this work. An early Superintendent of the Indian School Service, Ralph P. Collins, made it perfectly clear to the national commissioner what would be

10 The apparent fixation with "stages" is evident not only in Neo-Marxist arguments, but ironically, in classical economic arguments. Witness W.W. Rostow's (1960) famous "Stages of Economic Growth: A non-communist manifesto" document. So while the typology can be useful heuristically, assuming a historicity to the progress along these stages or modes of production is erroneous. 
necessary to change Zuni culture and practices. Unsurprisingly, Collins favored a combination of both disciplinary and civil society enforcements to transform the communally and tribally controlled landscape, into one of private Zuni land-owners. He carefully laid out the steps necessary for this change:

1. Make them leave the old village of Zuni and live upon their farms, the whole year around. The old village should be destroyed and deserted for sanitary reasons, if for no other. 2. Put all children in school, and make them attend regularly ten months of the year; and the more sent off the reservation the better. 3. Enforce the civil, religious, individual liberty and rights among them. (R. Collins 1901)

The first Bureau of Indian Affairs office at Zuni opened in 1902. Originally located in the main pueblo (town), the agency then moved to Blackrock. The Bureau's intent was to modernize agriculture at Zuni, to allot land parcels to individual farmers, and to instill in the Zuni the ideal of private ownership of property and entrepreneurship. Implied in the teleology of these policies and practices was that Zuni agriculture was primitive, inefficient, and that their social organization had to be shattered and rebuilt, to allow for more efficient means of land tenure and land-use.

Boarding schools became a very popular idea with Indian officials in order to break the influence of Zuni elders and parents over the younger generation. Education of the Federal type also weakened local knowledge and resource management practices, as elders deprived of pupils could not pass on the wisdom acquired by farming the desert for centuries. Again, this aspect was fundamental to the federal project occurring at Zuni, and was an important element to achieving agricultural hegemony. This aspect of reeducating peoples into a nationalizing context was also fundamental to Gramsci's description of the role of education in achieving new forms of hegemony. ${ }^{11}$ Logically, the "new education" movement focused on training the Zuni in vocational skills, but under the ideology of Western science. The Zuni were subjected to the same pejorative gaze and rhetoric of "modernizing agents," similar to Third World peoples caught within the web of development epistemologies today (M. Watts and R. Peet 1993). The insertion of Zuni into the modernizing flow of capital, irrigation works and efficiency had two prongs: large-scale reclamation projects and mechanized agriculture, as evidence by early reports on the reservation (M. McDowell 1919).

Signed in 1902, the Reclamation Act is one of the foundation pieces for remaking the hydrology of the American West, and also occurred in the same year as the construction of Blackrock dam at Zuni. The growing bureaucracy of the Office of Indian Affairs (later the Bureau of Indian Affairs) was able to lay claim to irrigation developments at Zuni. The Office initiated an "irrigation service” as early as 1901, and the new dam was to be the tool of changing the traditional Zuni practices of land tenure and uses. The plan was to turn Zuni into a "patriarchal, patrilineal society of farmers, with households under the control of fathers" (E. Hart 1985, p. 214). While physical changes in the landscape were the immediate reflection of ideology, this reordering and reshaping of gender were also clear interests in changing the social relations at Zuni. If material consequences were the final goals of this clearly gendered policy, officials were at least partially successful, as the famous "waffle gardens" cultivated by Zuni women were largely abandoned during the first half of the $20^{\text {th }}$ century, with only 2 remaining currently. When these officials spoke of agricultural improvements and household reforms, they largely focused on the male head of household, even when this ran counter to traditional Zuni custom. In addition, a strongly racialist tone undergirded nearly all language related to these changes, as one commissioner put it:

When the irrigation project is completed on the reservation, each family [head of household] can be given about ten acres of good land under the ditch...I think they will be in a position to make a good living if they only take advantage of their opportunities and take hold and work as white men do. (Oliver [1909] in E. Hart 1985).

Zuni was unable to escape the fervor and intensity of the ideological assault of "progressive, scientific" irrigation, following the general pattern in the American West (Worster 1985). Each (male) farmer was to be allotted ten acres of irrigable land within the new "Zuni Irrigation Project." The Zuni, in a show of defiance, commonly ripped out the staked boundaries and fences erected to divide these neat plots of land (T. Wessel 1987, p. 9). These small acts of defiance, resistance, and vandalism were part of the

11 “...with the first notions of the State and society as primordial elements of a new conception of the world which challenges the conceptions that are imparted by the various traditional social environments, i.e. those conceptions which can be termed folkloric...” (Gramsci 1971, p 30). 
discursive, debated nature of hegemony at Zuni, or what James Scott (1985) positively portrays as "weapons of the weak." Construction on the dam and canals, however, continued apace (as seen in Figure 3). Aside from the discourse of modern irrigation development, the Blackrock Dam was beset with structural problems during and upon completion of the project. Initially it was thought that about " 10,000 acres could be irrigated with such a dam," but the problems of structural failure and environmental sensitivity continuously lowered the optimistic estimates of irrigable land. As Blackrock dam neared completion in 1905, construction proceeded from the sides, leaving a small spillway right in the middle of the Zuni River bed. Spring floods, always substantial, cut ten feet along the bottom of the river bed. Nearly "20,000 acre-feet of water passed in twenty-four hours," and this cut would cause head ward erosion on all of the tributaries upstream from the dam site (E. Hart 1985, p. 225). After this initial failure, the consulting engineer for the dam, James D. Schuyler, stated that Blackrock is "an absolutely safe structure, and will always remain serviceable without danger of weakness or disaster from any future attack of the elements” (Schuyler in E. Hart 1985, p. 232).

With the dam completed in 1908, the acreage capability of the project was down-graded to 8,000 acres, but one engineer claimed "this acreage would be reduced to a larger degree" in drier years (E. Hart 1985, p. 235). As of June, 1908, Zuni were irrigating approximately 3,200 acres. The Zuni themselves were, of course, skeptical if not violently opposed to the idea of a dam project. An early inspection of the dam, upon completion, reveals that dissent remained. The report described how there remained "Indians (the older ones) who resent the construction of the Zuni dam and openly proclaim that a small little spring at the base of the dam, called by the Indians sacred spring, is of more benefit to them than the total amount of water impounded by the dam” (H. Hall, 1909). In late 1909, catastrophe struck when the dam's southern walls settled, then broke. Huge cracks in the land surrounding the dam appeared, as rills formed and some "5,000 cubic feet of water per second was flowing out of holes in the dam and under the spillway," eroding topsoil and crashing into the Zuni river bed (E. Hart 1985, p. 238). Efforts to control the new cycle of knick-point erosion on the Zuni river channel were rarely considered. Not until the 1920s would any expenditure for controlling fluvial erosion occur, and even then it employed Zuni traditional technology.

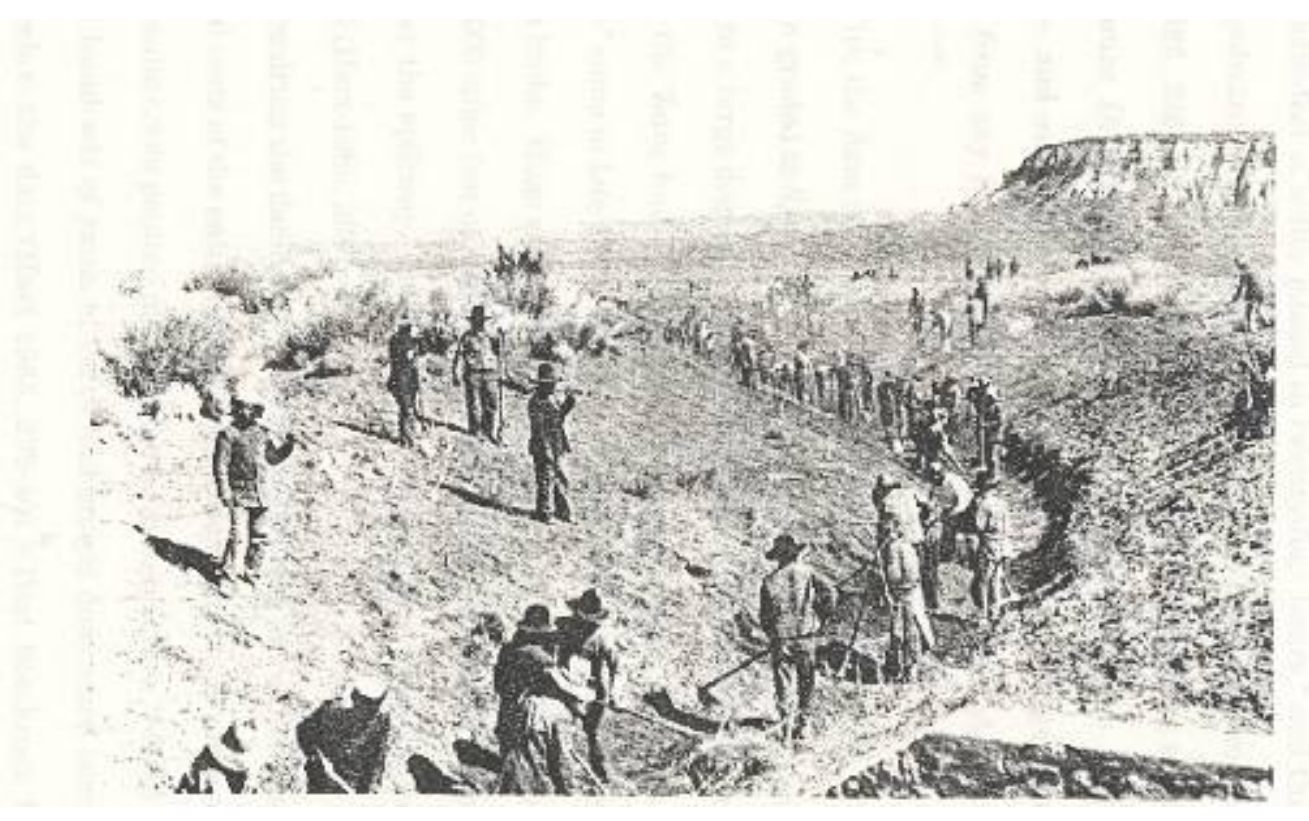

Figure 3. Main canal under construction from Blackrock Dam, ca. 1908. Photo courtesy of National Archives collection at Zuni Pueblo.

After the completion of the dam, however, rain-fed cornfields in the Zuni River valley were indeed converted to irrigated wheat fields. The new canals leading to the fields, along with new roads, channeled frequent floodwaters into the main pueblo, creating flood hazards. Serious water loss and siltation problems 
were visible as early as 1919, and the lack of irrigation water for the valley became severe in the 1930s. By the end of World War II, the Zuni who remained in the irrigation district had to haul water from small reservoirs. The project's failure also increased the number of Zuni dependent on wage labor during this period. By 1934, jewelry-making as wage income accounted for $86 \%$ of all earned income by the Zuni (B. Holmes and A. Fowler 1980, p. 211). By 1942, the figures had increased, and the Zuni were selling over half a million dollars' worth of jewelry (D. Leighton and C. Adair 1966). The concurrent reduction of the farming population led to increased canal disrepair and land abandonment (T. Ferguson and E. Hart 1985, pp. 81-82). These Zuni farmers who wished to farm after the project's failure were hard-pressed to do so, as they had already traded their land-use rights in the traditional farming districts for those in the irrigation district near Zuni pueblo (see Figure 4). Those who returned were increasingly influence by the Boa's efforts to mechanize the process of agriculture at Zuni.

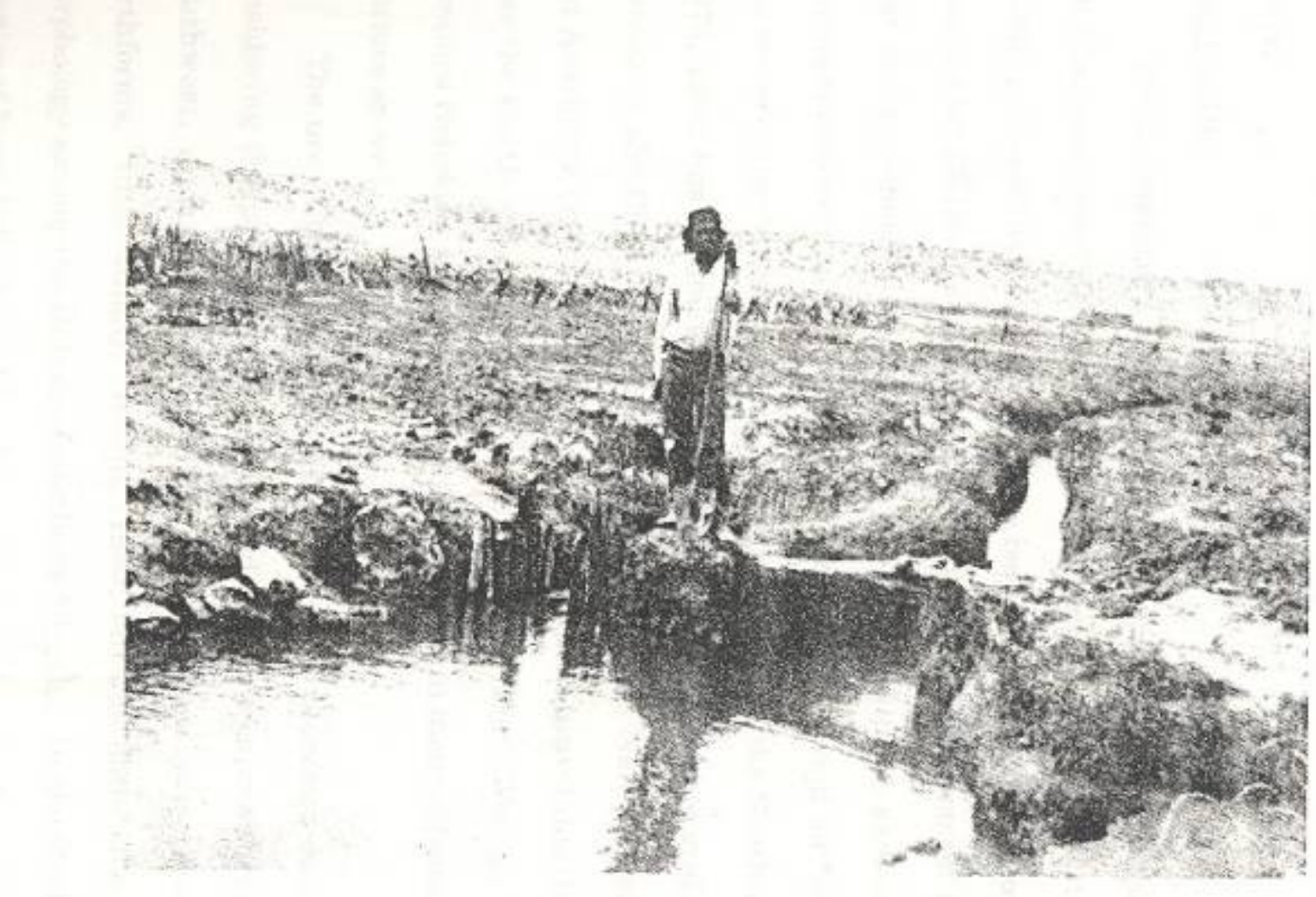

Figure 4. Zuni clearing and supervising canal in the irrigation district, ca. 1920s. Photo courtesy of National Archives collection at Zuni Pueblo.

With the failure of the entire irrigation project, the BIA at Zuni fumbled through a series of agronomy and range management experiments (C. McMillen 2000). Federal officials viewed the project at the time as a failure. Wessel $(1987$, p. 7) has nevertheless stated that the project could be viewed as successful for two reasons: the government confronted Zuni "cultural inertia” and the Zuni finally learned how to incorporate crops and techniques into their subsistence strategies. However, while the government did confront and occasionally undermine Zuni culture, they were not prone to "inertia" as Wessel argues. Throughout their history of relations with the Spanish and then Anglo-Americans, the Zuni convincingly showed their flexibility in adapting new crops to their livelihoods, such as livestock and orchards. New hybrids promoted by the U.S. Federal officials were also frequently used. The Zuni, clearly, did not suddenly realize the value of adopting new crops and techniques; they did so for centuries before their "experience in the valley" with the ruinous Federal irrigation project (cf T. Wessel 1987, p. 7). 
Many of the traditional practices of rain-fed agriculture at Zuni disappeared as irrigated agriculture and livestock management "districts” were established on the reservation. Seduced or induced to believing the rhetoric, the Zuni abandoned many of their traditional heirloom ("folk") crop varieties, despite their original importance in terms of religious symbolism and material value to rain-fed agriculture. While these traditional techniques can still be found at Zuni, the local knowledge critical to farming arroyos, alluvial fans and dry fields are distributed unequally. Only older Zuni, and a few still practicing rain-fed agriculture remember these techniques, although they are also modified from original descriptions left in the late $19^{\text {th }}$ Century.

Rain-fed agricultural fields not only allowed for flexible crop scheduling and labor allocation, they also helped to check arroyo formation and soil erosion, a problem not uncommon in the Southwest but whose ultimate cause is still poorly understood (R. Balling and S. Wells 1990). By using soil furrows and ridges, planting trees, and by using brush and soil embankments to evenly spread seasonal floodwaters or precipitation over a large area, Zuni farmers trapped precious water and valuable minerals from the silty stream load (Idiaque in T. Ferguson and E. Hart 1985). Field surface management was especially critical on steeper slopes and outwashes, and the Zuni gave each plant "a little ridge to hold water" (Panteah in T. Ferguson and E. Hart 1985) similar to the cepas described by Gene Wilken (1987) in Central America. Rain-fed fields on more level ground relied on a system of individual plant ridges, as well as larger ditches surrounding the field to provide drainage or sub-surface irrigation, and to deter livestock from moving into the planted areas of the field (Idiaque in T. Ferguson 1985, p. 6). Zuni farmers still practicing rain-fed techniques in the mid 1980s all agreed that plowing mechanically in rain-fed environments was risky, and that using a digging stick was preferable. Three principal reasons were identified. First plowing could "take all the moisture out" from the soil underlying the surface (Neymayah in T. Ferguson 1985, p. 13). Second, soil and crop damage can occur when cultivating, especially with a tractor, since they go deeper than digging sticks. Third, seed damage may be higher, and farmers may not see growing seedlings during early growth. While the practice continues at Zuni, most fields are now plowed with tractors, and are located on level lands with many types of soils. A few Zuni were still farming sandy soils with digging sticks, especially in the small canyons to the south of Zuni pueblo in the 1990s, but floodwater farming has been rendered nearly obsolete because of the nearly ubiquitous channel incisions that now traverse most fields once used in the past. A few remnant horticulturalists were attempting to revive some peach orchards on the side of Corn Mountain, the large mesa that dominates the central pueblo of Zuni. The bulk of this ancient orchard, however, lies in ruin - desiccated stumps that give testimony to the influence of Spanish missionary activities and introduced crops. Many of these same areas were also lost to livestock grazing as barbed wire fences were installed across the reservation, to divide sectors of pasture, disconnecting rain-fed and floodwater fields from their traditional users. The melting of the kachinas, of those spirits responsible for seasonal passings, harvests and hunting were perhaps presaged by McDowell's report who related that the Zuni were finally

...realizing...that prayer, dances, incantations and ceremonials for rain no longer are necessary to bring the precious water to their plowed fields. That, in time, this changing state of mind will weaken the influence of the rain priests and bring about other changes in the line of progress is almost a certainty”. (M. McDowell 1919)

\section{The Context of Agricultural Hegemony}

The early period of Zuni interaction with Anglo-Americans was typical for the Greater Southwest, and indeed, for most encounters with indigenous peoples in the U.S. These cultural contacts and accommodations were shaped during a flurry of military and scientific activities in the Southwest. The first thirty years of American rule (1848-1880) had little material significance for Zuni culture, and the only function that Zuni played for Anglo-Americans was that of guide, military ally, and purveyor of agricultural goods (B. Mills et.al. 1982, p. 26). In many ways, then, Zuni is no different from the pueblos along the Rio Grande in New Mexico. They were variously assimilated and influenced, even if a few have staunchly resisted total cultural infiltration (San Ildefonso is a good example of this). It should also be noted that not all BIA officials were complicit with the replacement of traditional land-uses and land tenure practices at Zuni. Many of the local commissioners out-posted at Zuni attempted to reason with national policies, by tempering their implementation, backed by those native voices in the Pueblo that viewed these changes with suspicion. The most famous of the Anglo-American observers was Frank Cushing (1981), whose near-wholesale adoption of Zuni cultural practices and dress during the early 1880s (1879-84) 
brought him into conflict with on-site CIA (later BIA) officers at the Pueblo, and remains in the literature as the most famous outside dissident to changes promoted on the reservation. This early phase, however, did establish the landscape discourse that enframed indigenous peoples within a new nationalizing context. The expeditions into the American Southwest to classify and categorize nature and landscape also assigned indigenous peoples to respective places or roles within that landscape.

Caught within a nexus of BIA development discourse, the Zuni resisted attempts by the government to cultural and economically integrate them. As discussed, the BIA attempted to dismantle and remold the physical, economic, and spiritual basis of life at Zuni over the course of 100 years. Establishing boarding schools on and off the reservation, bringing technology to Zuni farmers, and integrating Zuni into the regional and national economy were the immediate goals of the Bureau. Yet the personnel stationed at Zuni differentially applied the hegemonic impulses established in Washington's growing bureaucracy of dominating indigenous peoples throughout the American West. Though contested by the BIA and the oftrotating Superintendents at Zuni, theocratic rule of and by the Zuni survived into the $20^{\text {th }}$ Century, until around 1934 according to Ladd (1979, pp. 488-9). This theocratic religious system of governance, with its own legitimating discourse, provided a sound system of control for the Zuni and their resource management systems (T. Ferguson et al. 1988, p. 114). Contemporary witnesses of Zuni practices of communal land-ownership and management clearly support this idea. As late as 1919, letters to Indian Affairs testified that:

the Indians are successful dry farmers and raise considerable corn outside of the irrigated area. The women have gardens on the bank of the Zuni River... which are miniatures of their husbands' irrigated farms....the land is divided among the Zuni by mutual agreement and communal consent. A family 'owns' by right of selection, occupancy, and use and this right passes within the tribe as if the lands were owned in fee simple...If the irrigated lands there are allotted this system of holding property will complicate matters unless the allotment is made by some one who is quite familiar with the Zuni land matters (M. McDowell 1919).

Whether this system more closely represented a form of Zuni "social justice," however, is highly debatable. This tension between liberal, progressive ideology, and a retrospective cultural relativism is an unspoken strand of doubt within much of the political ecology literature. What is certain is that contemporary Federal officials and intellectuals fully realized both the indigenous power of land-ownership customs, and were fully cognizant as to what had to be done to break this communal arrangement, all of which was under a council of elders. As a final, parting shot, the same testimonial by McDowell (1919) added that the power of the Rain Priest should be taken away in order to speed the government's idea of development. BIA officials, who intended to compel the Zuni to adopt some form of democratic rule or representation, astutely manipulated the increase in political factionalism at Zuni. Superintendent Wright nicely encapsulates the typical view of the Zuni by officials and missionaries in this letter, to the Commissioner of Indian Affairs (Wright to C.I.A., 1900; E. Hart 1985, p. 215):

They carry on their ancient paganism without the semblance of regard for Christianity which is found as a mere compliance with the wishes of the white conquerors in the other pueblos. In the other [pueblos], pagan rites are more or less secret, here they are open.

Resistance by the Zuni, to the figurative and spatializing discourse of the government, took many forms. Allotment stakes were ripped out of the ground, a small and everyday form of resistance, during the period when irrigation districts and private land-ownership were being pushed by the BIA. When asked to neatly divide their communal or usufruct farming lands to geometric allotment patterns, the Zuni refused, and this resistance symbolized their alternative view of their own landscape. More was at stake in this constant bickering over natural vs. Cartesian boundaries of land and water. Zuni spiritual explanations in justifying the persistence of wetlands or natural springs were routinely ignored by the BIA who were intent on "reclaiming" land for irrigated agriculture. The Zuni did attempt to operate within the BIA system, and formally lodged letters and telegrams of protest. The Zuni, however, were rarely consulted on the surveys used to allocate lands and divide resources.

After World War II, the Federal government practically abandoned matters of indigenous land and resource policy. The 1950s and early 60s have been called the "termination period" as the Federal government attempted to remove supports and engagements with native groups. During Johnson's "war on poverty," some Federal funds were renewed at Zuni, and increase in political and social activism led to 
greater consciousness at Zuni. In 1970, the Zuni became the first tribal group in the U.S. to adopt a constitution. For the past thirty years, the BIA has elected a policy of "non-policy" at Zuni, although small projects are still underway on the reservation. The latest installment of Federal control was the use of PVC tubing for irrigation agriculture at Zuni, to reduce evapotranspiration, but in the process Zuni access to water was being affected.

\section{Conclusion and Postscript}

During the mid 1990s, a Zuni Conservation Project began operating on the reservation, with the goal of documenting and monitoring areas for agricultural and ecosystem restoration, funded by a court settlement between Zuni and the U.S. government. Recovering and disseminating traditional Zuni heirloom crops, such as multi-colored corn varieties, were identified as particularly important avenues for restoring agro-diversity and landscapes at Zuni, although there is continued ambivalence about the access of seed by outsiders on reservation lands (C. Brandt 1992). Public meetings were held by the Zuni Conservation Project to identify areas of concern to the community, and to encourage participation in the overall plans for sustainable agriculture, even if the underlying cultural infrastructure has changed on the reservation.

During the mid-1990s, the BIA countered with its own offering of workshops on agriculture, including visits to large, mechanized irrigation farm districts in southern New Mexico and Florida. While impressed, one of the Zuni participants noted that they didn't have resources like that, especially water (D. Cleveland 1998). So while Gramsci originally intended the idea of hegemony (in the cultural-political sense) to be a reflection of the non-visible forms of media and political domination that is accepted as "normal" or "common sense,", the extension of his work to the physical incorporation, domination and transformation at Zuni is also tangible. Black Rock Dam, the canal works, the now abandoned irrigation fields, the dispersion of Zuni throughout and outside of the reservation, are all visible after-effects of this agricultural hegemony. Understanding this grounded theory, and the influence of intellectuals in landscaping power into culture, illustrates the importance of these early ideas and ideologies at Zuni.

The political ecology of agricultural and environmental governance, however, is constantly being rewritten at Zuni. How convincing has this constant rhetoric of physical and "spiritual" improvement been? Traditional forms of agriculture have all but disappeared, or at least, those described by the first Spaniards or - later - by Frank Cushing in the 1880s. Yet vital signs of Zuni agriculture remain, such as the preservation of colored corn crops, critical for ceremonial purposes. An older Zuni man has taken it upon himself to attempt peach tree restoration, by using a technique employed by his grandfather, though on a limited scale. One of the more recent and notable efforts has been a beaver restoration project, in an attempt to stabilize stream ecology and riparian erosion, and this has had some degree of success (S. Albert and T. Trimble 2000). So no wholesale hegemony, administrative or ideological, was achieved at Zuni - a point that Gramsci made clear in his original writings. This use of "hegemony" also must be properly understood in the context of BIA officials, who at no point in time intended any ill-will towards the Zuni, and whose actions must be understood within the larger historical framework of U.S. Federal policy towards indigenous peoples. There were dissenting opinions on actions at Zuni within the BIA, quite apart from the well-known voice of Cushing, and only the policies and resulting effects are critiqued here. The importance of the humanized Zuni landscape is also widely evident in crafts, from pottery to jewelry, perhaps symbolizing a nostalgic sense of natural and cultural capital that remains strong. ${ }^{13}$ The BIA continues its work of modernizing agricultural extension; the Zuni are now spread throughout the Southwestern U.S., attempting to incorporate these difficult notions of progress into their own lives. Just as balancing modernity and tradition was a challenge at Zuni, so it has been for all indigenous peoples of the Americas, despite differing contexts and policy environments across nation states and political regimes (M.

\footnotetext{
${ }^{12}$ The term "common sense” is a slippery one when discussing the ideas and use of such phrasing in Gramsci's original texts. By this, in Italian, Gramsci was most commonly using the meaning of "good sense." It does not, however, excuse the inner contradiction of using "common" and "good" sense interchangeably in much of his notes.

${ }^{13}$ It is well-established that silver-smith work at Zuni was highly influenced (if not imported) by the Navajo as early as the 1850s. Current Zuni work emphasizes their original skills in lapidary, incorporating the use of in-laid precious stones, as they are crafted into silver jewelry. Pottery at Zuni has also taken and borrowed elements already present at Zuni, as well as those from surrounding pueblo influences, like Acoma in Western New Mexico.
} 
Jaimes 1992). The ideology and practices of social change has varied over time and space, yet the early modern period remains crucial, yet understudied, to understanding current reservation landscapes.

\section{References Cited}

Albert, S. and T. Trimble.

2000. "Beavers are Partners in Riparian Restoration on the Zuni Indian Reservation". Ecological Restoration 18(2): 87-92.

Balling, R.C. Jr. and S. Wells.

1990. "Historical Rainfall Patterns and Arroyo Activity Within the Zuni River Drainage Basin, New Mexico”. Annals of the Association of American Geographers 80(4): 603-17.

Bassett, T.J.

2001. The Peasant Cotton Revolution in West Africa: Côte D’Ivoire, 1880-1995. Cambridge and New York: Cambridge University Press.

Blaikie, P.M. and H.C. Brookfield.

1987. Land Degradation and Society. London: Methuen.

Brandt, C.B.

1992. "Preserving Traditional Crops in Rural Indigenous Communities: An Example from the Pueblo of Zuni”. Paper Presented at The $15^{\text {th }}$ Annual Meeting of The Society of Ethnobiology, March, Washington D.C.

Butzer, K.W.

1992. “The Americas Before and After 1492: An Introduction to Current Geographical Research”. Annals of the Association of American Geographers 82(3): 345-68.

Collins, R.P.

1901. Letter to the Superintendent of the Indian School Service to the Commissioner of Indian Affairs (CIA), March $9^{\text {th }} . \operatorname{Rg} 75, \mathrm{Lr}, \mathrm{Na}$.

Cleveland, D.A.

1998. "Indian Agriculture, United States Agriculture, and Sustainable Agriculture: Science and Advocacy”. American Indian Culture and Research Journal 22(3): 13-29.

Cleveland, D.A, D.F. Eriacho, F. Bowannie, Jr., A. Laahty, and E.P. Perramond.

1995. “Zuni Farming and The U.S. Government: The Politics of Biological Diversity”. Agriculture and Human Values 14: 2-18.

Crehan, K.

2002. Gramsci, Culture and Anthropology. Berkeley: University of California Press.

Cushing, F. and J. Green.

1981. Zuni: Selected Writings of Frank H. Cushing. Lincoln: University of Nebraska Press.

Denevan, W.M.

1992. "The Pristine Myth: The Landscape of the Americas in 1492". Annals of the Association of American Geographers 82(3): 369-85.

Doolittle, W.E.

1992. "Agriculture in North America on the Eve of Contact: A Reassessment”. Annals of the Association of American Geographers 82(3): 286-401.

Doolittle, W.E.

2000. Cultivated Landscapes of Native North America. Oxford: Oxford University Press. 
Ferguson, T.J. and E.R. Hart. 1985.

A Zuni Atlas. Norman: University of Oklahoma Press.

Ferguson, T.J., E.R. Hart and C. Seciwa.

1988. Twentieth Century Zuni Political and Economic Development in Relation to Federal Indian Policy. In Public Policy Impacts on American Indian Economic Development, ed. C. Matthew Snipp, 113-44. Albuquerque: Native American Studies, University of New Mexico, Development Series No. 4.

Fish, S.K. and P.R. Fish, Eds.

1984. "Prehistoric Agricultural Strategies in the Southwest". Tempe (AZ): Anthropological Research Papers, No. 33.

Foreman, G, ed.

1941 (reprinted 1968). A Pathfinder in the Southwest. The Itinerary of Lieutenant A. W. Whipple during his Explorations for a Railway Route from Fort Smith to Los Angeles in the Years 1853 \& 1854. Norman, University of Oklahoma Press.

Gade, D.

1992. "Landscape, System, and Identity in the Post-Conquest Andes". Annals of the Association of American Geographers 82(3): 460-77.

Gramsci, A.

reprinted 1971. Selections from the Prison Notebooks. New York: International Publishers.

Harley, J.B.

1988. Maps, Knowledge, and Power. In The Iconography of Landscape, D. Cosgrove, D. and S. Daniels, editors. Cambridge: Cambridge University Press.

Hall, H.

1909. Inspection Report, September $7^{\text {th }}$. Rg 75, Cf, Na.

Hart, E.R.

1985. Damage to Zuni Trust Lands. Zuni Tribe vs. United States of America, Docket 327-81l. Exhibit \#1000. Zuni, NM.

Holmes, B.E. and A.P. Fowler.

1980. The Alternative Dams Survey: An Archaeological Sample Survey and Evaluation of the Burned Timber and Coal Mine Dams. Zuni Indian Reservation: Zuni Pueblo, Zuni Archaeology Program.

Hoxie, F.E. 1984.

A Final Promise: The Campaign to Assimilate the Indians, 1880-1920. Lincoln: University of Nebraska Press.

Jaimes, M.A.

1992. The State of Native America: Genocide, Colonization, and Resistance. Boston: South End Press.

Keesing, R.M.

1994. “Colonial and Counter-Colonial Discourse in Melanesia”. Critique of Anthropology 14(1): 41-58.

Kintigh, K.

1985. Settlement, Subsistence, and Society in Late Zuni Prehistory. Tucson: Anthropological Papers of the University of Arizona No. 44.

Kurtz, D.V.

1996. "Hegemony and Anthropology: Gramsci, Exegeses, Reinterpretations”. Critique of Anthropology 16(2): 103-35. 
Leighton, D.C. and J. Adair.

1966. People of the Middle Place: A Study of the Zuni Indians. New Haven: Human Relations Area Files, Inc.

Makabe, T.

1999. "Ethnic Hegemony: The Japanese Brazilians in Agriculture, 1908-1968”. Ethnic \& Racial Studies 22(4): 702-23.

Maxwell, Jr., T.J.

1956. "Agricultural Ceremonies of the Central Andes During Four Hundred Years of Spanish Contact". Ethnohistory 3(1): 46-71.

McDowell, M.

1919. On the Zuni Indian Reservation. Unpublished Report, Ms on File at Zuni Pueblo Archives.

McMillen, C.W.

2000. "Rain, Ritual, and Reclamation: The Failure of Irrigation on the Zuni and Navajo Reservations, 1883-1914”. Western Historical Quarterly 31(4): 434-456.

Mills, B.J., B.E. Holmes, and T.J. Ferguson.

1982. Performance Report for an Architectural and Ethnohistorical Study of The Zuni Farming Villages. NEH Grant No. Rs-0792-78.

Moore, D.S.

1996. Marxism, Culture, and Political Ecology: Environmental Struggles in Zimbabwe's Eastern Highlands. In Liberation Ecologies: Environment, Development, Social Movements. R. Peet and M.J. Watts, editors, Pp. 125-147. London: Routledge Press.

Offen, K.H.

2004. “Historical Political Ecology: An Introduction”. Historical Geography 32: 19-42.

Peet, R. and M.J. Watts.

1996. Development, Sustainability, and Environment in an Age of Market Triumphalism. In Liberation Ecologies: Environment, Development, Social Movements, Eds. R. Peet and M.J. Watts, Pp. 1-45. London: Routledge Press.

Perramond, E.

1994. An Historical Geography of Zuni Agriculture. MA thesis, Louisiana State University, Department of Geography and Anthropology.

Pratt, M.L.

1991. Imperial Eyes: Travel Writing and Transculturation. London: Routledge Press.

Prucha, F.P.

1988. United States Indian Policies, 1815-1860. In Sturtevant, W.C. (Ed): Handbook of North American Indians, Vol.4. Washington, Smithsonian Institution.

Rostow, W.W.

1960. The Stages of Economic Growth: A Non-Communist Manifesto. Cambridge: Cambridge University Press.

Scott, J.

1985. Weapons of the Weak: Everyday Forms of Peasant Resistance. New Haven and London: Yale University Press.

Simpson, J.H.

1964 (reprinted 2003, edited by F. McNitt). Navaho Expedition. Norman: University of Oklahoma Press. 
Sluyter, A.

2002. Colonialism and Landscape: Postcolonial Theory and Applications. Lanham MD: Rowman \& Littlefield.

Spurr, D.

1993. The Rhetoric of Empire: Colonial Discourse in Journalism, Travel Writing, and Imperial Administration. Durham: Duke University Press.

Swyngedouw, E.

1999. "Modernity and Hybridity: Nature, Regeneracionismo, and Production of the Spanish Waterscape, 1890-1930”. Annals of the Association of American Geographers 89(3): 443-65.

Vogeler, I.

1996. "State Hegemony in Transforming the Rural Landscapes of Eastern Germany, 1945-1994”. Annals of The Association of American Geographers 86(3): 432-58.

Watts, M.J. and R. Peet.

1993. "Development Theory and Environment in an Age of Market Triumphalism". Economic Geography 69(3): 227-53.

Wessel, T.R.

1987. "Phantom Experiment Station: Government Agriculture on the Zuni Reservation”. Agricultural History 61(4): 1-12.

White, R.

1984. The Roots of Dependency: Subsistence, Environment and Social Change Among the Choctaws, Pawnees, and Navajos. Lincoln: University of Nebraska Press.

White, R.

1991. "It's Your Misfortune and None of My Own:” A History of the American West. Norman: University of Oklahoma Press.

Wilken, G.

1987. Good Farmers: Traditional Agricultural Resource Management in Mexico and Central America. Berkeley: University of California Press.

Worster, D.

1985. Rivers of Empire: Water, Aridity, and the Growth of the American West. Oxford and New York: Oxford University Press.

Zimmerer, K.S.

1996. Changing Fortunes: Biodiversity and Peasant Livelihoods in the Andes. Berkeley: University of California Press. 


\begin{abstract}
An historical political ecology of Zuni Pueblo illustrates several processes that led to native agricultural decline in the region. Modern indigenous agriculture, and its associated techniques or practices, is marginalized within the literature. The reasons for the decline of traditional agricultural management at Zuni, as for much of the Southwestern United States, are complex. U.S. federal policies aimed at breaking indigenous theocractic rule, reforming land tenure, and modernizing reservation agriculture all contributed to this process at Zuni Pueblo. Underlying the material changes were also several conceptual or ideological processes that served the same purpose, and one that can be termed agricultural hegemony. The replacement of the Zuni kachinas, icons of discipline within traditional ceremonial roles, with those of modern agricultural sciences and practices were fundamental to the eventual outcome.
\end{abstract}

Key words: Zuni Pueblo, agriculture, landscape, native policy, hegemony, historical political ecology.

\title{
Résumé
}

Une écologie politique et historique du Pueblo Zuni met en lumière plusieurs processus qui ont mené au déclin de l'agriculture indigène de la région. L'agriculture indigène moderne, ainsi que les techniques et pratiques qui y sont associées, sont passées sous silence dans la recherche scientifique. Les raisons du déclin de l'agriculture traditionnelle à Zuni, tout comme celle du sud-ouest des Etats-Unis, sont complexes. Les politiques du gouvernement federal visant à ruiner l'autorité théocratique indigène, à réformer le régime foncier et à moderniser l'agriculture de la réserve ont toutes contribué à ce processus au Pueblo de Zuni. A la base de ces changements matériels il y a aussi plusieurs processus conceptuels ou idéologiques qui ont contribué à ce méme processus que l'on peut appeler $<<$ hégémonie agricole $>>$. Le remplacement des kachinas Zunis, icones de discipline dans les rôles cérémoniaux traditionnels, par ceux ces sciences agricoles et pratiques modernes est responsable du résultat final.

Mots-clés : Pueblo de Zuni, agriculture, paysage, politiques indigènes, hégémonie, écologie politique et historique.

\section{Resumen}

Una perspectiva utilizando la ecología política e histórica del Pueblo de Zuni ilumina varios procesos que han contribuido a la decadencia agrícola de la región. La agricultura indígena contemporánea, y sus prácticas y técnicas asociadas, han sido marginalizadas en la literatura. Las razones por el decaimiento del manejo agrícolo tradicional en Zuni, como en todo el suroeste de los Estados Unidos, son complejas. Las estrategias nacionales estadounidenses que proponen la quiebra de la autoridad teocrática, reformas de tenencia de tierras, y la modernización agrícola de la reserva indígena contribuyeron a este proceso en Zuni Pueblo. Debajo de los cambios materiales se encontraban procesos ideológicos y conceptuales que sirvieron al mismo proceso, uno que se puede describir como hegemonía agrícola. El reemplazo de las kachinas de Zuni, íconos de disciplina en los papeles ceremoniales tradicionales, con los de las ciencias agrícolas modernas son fundamentales al resultado final.

Palabras claves: Zuni Pueblo, agricultura, paisaje, política indígena, hegemonía, ecología política e histórica 